\title{
The Competition of Slave and Free Labor in Artisanal Production: Buenos Aires, 1770-1815
}

\author{
LYMAN L. JOHNSON
}

\begin{abstract}
Summary: Between 1770 and 1815 the population of Buenos Aires nearly doubled. Despite this impressive growth, the city and its hinterland suffered from a chronic labor shortage. Efforts to expand artisanal production were undermined by the resultant high wage levels. Similar problems affected the countryside where slaves and the forced labor of Indians and convicts failed to meet harvest needs. This paper examines the competition among these forms of labor. Economic, social and cultural factors that helped determine the allocation of labor types are also analyzed. Finally, since scores of slaves and Indian laborers gained freedom and entered the labor market each year, the economic and cultural factors that facilitated this movement are examined.
\end{abstract}

Little attention has been paid to wage labor in the history of colonial Spanish America. Yet, across the empire, wage labor was increasingly important in urban manufacturing and service sectors and in mining from the mid seventeenth century. By the late eighteenth century, the skilled trades of the empire's largest cities and towns relied primarily on wage laborers. Both transportation and construction were also largely dependent on wage labor. Although some urban economies retained their early dependence on the coerced labor of Indians and slaves, the most dynamic urban economies of Spanish America were moving dramatically in the direction of wage labor by the end of the colonial period. Nevertheless, the coerced components of both rural and urban production have received much greater attention from historians and other social scientists. Slave labor and the coercive labor systems imposed on indigenous peoples such as the Andean mita have attracted the interest of some of Spanish America's most distinguished historians. In particular, the slave labor systems of the major Iberian sugar-producing plantation societies of Brazil and Cuba have been explored in depth. In addition, there are a number of excellent studies of the plantation sectors of colonial Venezuela, Ecuador and Peru. A similar concentration on forms of coerced labor is found in the social historical and economic scholarship devoted to mining and manufacturing enterprise in late eighteenth-century Spanish America. The Potosi mita and the use of coerced Indian workers in the textile obrajes of New Spain and Quito have also attracted re-examination. But what is known of the wage

International Review of Social History 40 (1995), pp. 409-424 
workers who labored alongside these coerced workers? And, more broadly, how did these two systems of allocating labor interact in response to changes in these colonial economies?

Despite more than forty years of intensive interrogation of the region's economic development in the late colonial period, there are only a handful of wage and real wage studies. As a result, we know little about changes in labor demand or, alternatively, changes in compensation and living conditions experienced by the mass of wage laborers. Other issues associated with wage labor such as recruitment, employment patterns, training and work discipline have been similarly ignored. In cities like Buenos Aires where wage laborers provided the majority of both skilled and unskilled labor pools, our knowledge of both social structure and economic performance are obscured by these limitations in the literature.

Although coerced labor of various kinds (including debt peonage and convict labor) remained important, if not central, to export agriculture in Spanish America well into the national period, wage labor came to hold an important place in the production process even in plantation zones. On the sugar plantations of Cuba and the cacao plantations of Venezuela, for example, skilled jobs were often filled by wage laborers by 1800 . Outside the plantation economies free labor was proportionally more important. Although slaves were present in large numbers until eventual abolition of slavery in 1861, the agriculture and livestock sectors of the province of Buenos Aires and neighboring Uruguay depended more on free than slave labor.

In this essay I offer an analysis of the relationship between slave and free labor regimes in the city of Buenos Aires and its immediate agricultural hinterland during the period 1770-1815. I begin with an overview of the region's economic history in the late colonial period and then turn to a more detailed discussion of labor supply and workforce distribution. The integration of slaves in the urban wage labor force and the impact of increased numbers of slaves on wage rates will be discussed. In a brief postscript, I trace the region's labor history to the final abolition of slavery in the province of Buenos Aires in 1861.

\section{THE EARLY ECONOMY IN BUENOS AIRES}

Although Buenos Aires was permanently settled early in the colonial cycle in 1580 , the city's growth was retarded by imperial policies that placed narrow limits on direct trade with Europe and with interior provinces. Until the last half of the eighteenth century, Atlantic trade was monopolized by merchant guilds in Seville and a small number of American colonial cities. Only in 1778 did the merchant guild of Lima lose its control of Buenos Aires' commerce. This cumbersome and costly dependence on Lima restricted the city's commercial links with the developing Atlantic market and slowed economic development. Never- 
theless, Lima's commercial monopoly serviced the Spanish Crown's desire to limit the illegal exchange of American bullion for contraband goods provided by European rivals. Because the region's major products (livestock by-products and yerba mate or Paraguayan tea) were burdened by a low value to bulk ratio, these trade restrictions nearly eliminated the possibility of legal trade for Spain's South Atlantic colonies. Only the hugh profits from the illegal trade in silver kept commerce alive by drawing Spain's European rivals to the Río de la Plata.

Commercially marginalized by Crown policy, the city, along with Montevideo and Colonia on the east bank of the estuary, eventually won a niche in the Atlantic market as a center of contraband. Despite increased efforts by Spain to control trade to the region by augmenting coast guard and customs service scrutiny, French, Dutch, English and Portuguese merchants continued to exchange prohibited imports for silver produced at Potosí and a significant share of the region's production of low-profit livestock by-products that served in effect as ballast on the ships returning to Europe with silver. As a result, foreign goods dominated the regional market until the founding of the viceroyalty of Río de la Plata in 1776.

Slaves were among the prohibited goods imported at Buenos Aires. Official records indicate that a total of 22,892 slaves entered the city between 1595 and $1680 .{ }^{1}$ The vast majority of these slaves were imported by foreign merchants with the connivance of Spanish officials who permitted foreign captains to off-load and sell slaves after claiming their ships had been damaged by storms. In other cases, slaves were "confiscated" and sold by Crown officials who then compensated foreign merchants under the table. Many scholars believe the actual number of slaves entering Buenos Aires during this period may have been double the official count.

Regardless of the actual volume of the slave trade before 1700 , it is clear that very few slaves remained long in Buenos Aires or its immediate hinterland. The majority of slaves followed the trail of illegal silver back to its origin in Potosí. The disproportionate flow of slave labor to the Andean zone effectively represents the competitive labor demands of Buenos Aires and the Andean mining zone. Although Potosí and other Andean silver mining regions experienced a steep decline in production in the seventeenth century, the expensive labor of African slaves continued to be allocated by market forces to the Andean region rather than to Buenos Aires.

The distribution of slaves in the labor force of the city of Buenos Aires confirms this summary judgement. In the early eighteenth century, less than 20 per cent of all slaves were concentrated in the city's artisan shops or employed in the nearby agricultural sector. Instead, the majority

${ }^{1}$ George Reid Andrews, The Afro-Argentines of Buenos Aires (Madison, 1980), p. 24. 
of the Río de la Plata region's slaves were placed as household servants. That is, slave labor was more associated with establishing the status of elite households than with producing income. The limited profitability of manufacturing and agriculture before the Bourbon Reform era could not sustain reliance on this form of expensive coerced labor.

\section{THE ECONOMY IN THE ERA OF THE BOURBON REFORMS}

The Río de la Plata region benefited enormously from the altered geopolitical and economic policies of the Bourbons. After 1700 the port of Buenos Aires was incrementally opened to direct trade with Spain and other Spanish colonies. In an effort to staunch the flow of contraband silver and thwart Portuguese military and commercial ambitions in the region, the Spanish Crown made Buenos Aires the capital of a new viceroyalty in 1776. By including the mining region of Alto Peru (Bolivia) in the viceroyalty, the Crown both recognized the city's historic role as exporter of Potosís silver and provided the means to pay for the city's greatly expanded civil and military responsibilities. In 1778, as part of an empire-wide commercial reform, Ordinance of Free Trade, Buenos Aires was given greatly expanded commercial access to Spain and to Spanish colonial markets.

The impact of these reforms is reflected in the growth of urban population. From a population of approximately 9,000 in 1720 , Buenos Aires grew to more than 60,000 in 1810 , rivaling in size the ancient viceregal capital of Lima. ${ }^{2}$ While rural population growth lagged behind the city's upward trajectory, increased urban demand for food and expanded access to European and Western Hemisphere markets for livestock by-products created new economic opportunities in the countryside as well. Between 1781 and 1798, the frontier town of Chascomús, for example, grew from 374 to 1,000 inhabitants. This rate of growth was general in the region with the rural commercial center of Luján growing five-fold to over 2,000 inhabitants in this same period.

\section{SLAVES AND WAGE LABORERS IN THE VICEREGAL ECONOMY}

In both the city and countryside, economic expansion after 1776 initiated a long period of chronic labor shortage that persisted until the era of large-scale immigration in the 1880s. This labor shortage, and resulting high wages, was a constant theme in the reports of colonial officials, the records of the town council (cabildo), and in the official and private correspondence of local merchants and foreign visitors. Both local and viceregal governments debated, and in some cases attempted, an array

\footnotetext{
${ }^{2}$ See my "Estimaciones de la población de Buenos Aires en 1744, 1778, y 1810", Desarrollo Econónmico, 19, 73 (1979), pp. 107-120.
} 
of schemes to meet the region's labor needs. As these pressures mounted, Crown officials effectively suspended long-standing imperial prohibitions that barred the immigration and residency of foreign nationals and actively petitioned for direct participation in the slave trade.

Because references to labor shortages are so common in the documents, nearly every scholar of the late colonial period has mentioned the issue. Yet there have been very few substantial efforts by colonial economic and social historians to examine labor supply in the Río de la Plata region. Among the small number of scholars who have discussed the regional labor market, research has been concentrated on rural labor supply in the era following independence. ${ }^{3} \mathrm{~A}$ similar concern with rural labor supply has also dominated the much more limited literature devoted to the colonial period. ${ }^{4}$ As a result, the discussion of colonial labor supply is most commonly illustrated by the efforts of viceregal and municipal governments to provide harvest labor by compelling the shortterm labor of Paraguayan Indians, convicts and beggars. Larger issues, like the effect of high wages on regional development, have been largely ignored.

\section{THE URBAN LABOR MARKET TO 1815}

Slaves provided an important component of the city's labor force to the end of the colonial period. Between 1696 and 1750 the Crown granted monopoly control of the slave trade to Buenos Aires to a succession of foreign companies. The Portuguese Caheu Company held the monopoly initially, but was forced to relinquish control due to poor performance in 1701. The monopoly was then granted to the French Guinea Company. Following the War of Spanish Succession, the British South Sea Company exercised the monopoly until 1748. During the period of the French and British monopolies, a total of approximately 14,000 slaves legally entered Buenos Aires.

As was true in the seventeenth century, the majority of slaves imported before 1750 were quickly shipped to other destinations. Of the approximately 11,000 slaves imported by the British monopoly between 1715 and 1738 only 30 per cent, or approximately 3,300, stayed in Buenos Aires and its rural hinterland. ${ }^{5}$ The majority were sent to interior towns,

${ }^{3}$ Richard W. Slatta, Gauchos and the Vanishing Frontier (Lincoln, Nebraska, 1983), especially ch. 7.

4 Among the many recent contributions see Carlos Mayo, "Estancia y peonaje en la región pampeana en la segunda mitad del XVIII", Desarrollo Económico, 92 (1984), pp. 609-616 and Ricardo Salvatore and Jonathon Brown, "Trade and Proletarianization in the Colonial Banda Oriental. Evidence on the Estancia de las Vacas, 1791-1805", Hispanic American Historical Review, 67 (1987), pp. 431-459.

${ }^{3}$ Data for the last decade of the British asiento are fragmentary. See Elena F. Scheuss de Studer, La trata de negros en el Río de la Plata durante el siglo XVIII (Buenos Aires, 1958). 
Table 1. Legal slave imports to Buenos Aires, 1750-1806

\begin{tabular}{lrr}
\hline Year & Total & Per year \\
\hline $1750-1759$ & 1,214 & 121 \\
$1760-1769$ & 397 & 40 \\
$1770-1779$ & 475 & 48 \\
$1780-1789$ & 2,806 & 281 \\
$1790-1799$ & 9,013 & 901 \\
$1800-1806$ & 13,256 & 1,326 \\
\hline
\end{tabular}

Sources: These figures are based on my search of Aduana and Consulado records held by the Archivo General de la Nación in Buenos Aires, Argentina.

to the Andean mining zone, or to Chile. Both Chile and Alto Peru took slightly larger shares of total slave imports than Buenos Aires.

Legal importations of slaves totaled approximately 28,000 in the period 1750-1806. Actual importations probably reached 50,000 due to continued contraband. As illustrated in Table 1, legal slave imports were very limited through the 1770 s. $^{6}$ Slave imports then increased in response to the economic stimulus provided by the creation of the new viceroyalty and the opening of direct trade with Spain and other Spanish colonies. Although European wars disrupted trade repeatedly during the period 1790-1806, slave imports increased steadily as local merchants were permitted to enter the direct trade with Africa and as the ships of neutral nations were granted access to the Buenos Aires market. Slave ships captured by local privateers also contributed to this rising tide of slave imports. As a result, 82 per cent of total legal slave imports for the 57-year period 1750-1806 landed during the final seventeen years.

Unfortunately, we lack records for the period after 1778 that would allow us confidently to compare with earlier periods the percentage of slave imports retained by the city and its hinterland relative to those re-exported to other locations. However, the surviving evidence seems to suggest that at least a majority of the slaves who entered Buenos Aires after 1778 stayed in the city or the nearby countryside. Contemporary census records provide the outline of this altered pattern in the slave trade. The city's black and mulatto population (slave and free) increased from 16.9 per cent of the population in 1744 to 33 per cent in 1810. During this same period, the percentage of slaves in the black and mulatto population of the city of Buenos Aires rose from 75 to

\footnotetext{
6 These sources clearly under-represent actual arrivals. Some scholars have put the total for the period $1740-1822$ at more than 45,000 . The importance of the contraband slave trade is suggested by the altered racial distributions found in contemporary censuses. These sources indicate that the African-originated population of the city rose from 17 per cent in 1744 to 29 per cent in 1778. See Marta B. Goldberg and Silvia C. Mallo, "La población africana en Buenos Aires y su campana. formas de vida y de subsistencia (17501850)", Temas de Africa y Asia, Facultad de Filosofia y Letras, Universidad de Buenos Aires (1993), pp. 15-69.
} 
86.3 per cent. ${ }^{7}$ Nevertheless, even while the labor needs of this rapidly expanding urban economy promoted the expansion of slave holding in Buenos Aires, a steady stream of men and women gained their freedom through manumission and entered the pool of free labor. ${ }^{8}$ Moreover, large numbers of those who remained in bondage operated with substantial independence in the local labor market, seeking work and negotiating wages with little direct supervision by their owners.

That is, the expanding economy of late colonial Buenos Aires produced seemingly contradictory results relative to our common assumptions about the competition between slave and free labor. The long period of sustained labor demand and high wages initiated by imperial reforms made the purchase of large numbers of costly slaves feasible for the first time in the city's history. But the same expansion that promoted the growth of the slave population seems also to have produced significant opportunity for manumission and remarkable levels of independence for those who remained in bondage. Moreover, the expansion of slavery generally and the integration of slaves into artisanal and other skilled manual occupations apparently occurred without depressing the wages or limiting the employment opportunities of free workers.

The importance of slavery to the economy of late colonial Buenos Aires is indisputable. Nearly every contemporary account by a foreign visitor or Crown official noted the importance of slave and free black labor to the city. Many simply stated that blacks and castas dominated all the urban trades, including the most-skilled artisan crafts, the urban service sector and domestic service. ${ }^{9}$ In each of these employment sectors, slave participation expanded rapidly after 1790 .

Travelers as well as local residents commonly drew attention to two additional features of the local slave regime. Although there were some substantial slave holdings in the city, as was true in all the Spanish American capitals, there were very large numbers of slave owners in late colonial Buenos Aires who owned only a single slave. Within the slave owning population, a small number of wealthy individuals did own large numbers of slaves. Wholesale merchants, high-ranking royal officials, and some artisan manufacturers (especially bakers and owners of

\footnotetext{
7 See Lyman L. Johnson and Susan M. Socolow, "Población y espacio en el Buenos Aires del siglo XVIII", Desarrollo Económico, 20, 79 (1980), especially pp. 332-334.

8 It is difficult to assert with confidence a manumission rate for Buenos Aires, or any other colonial city, but a close analysis of the surviving notarial records indicates that by the last decades of the colonial period just under 1.5 per cent of the slave population gained freedom each year. See my "Manumission in Colonial Buenos Aires, 1776-1810", Hispanic American Historical Review, 59 (1979), pp. 258-279.

9 Most of these sources suggest that only 20 per cent of the urban population was white. The difference between the census counts and the perceptions of visitors to the city reflects the necessarily imprecise line that separated "white" from "mulatto" in colonial Buenos Aires. Where visitors saw mulattoes, locals often saw whites. See Goldberg and Mallo, "La población Africana", p. 18.
} 
brick factories) had the largest holdings, in some cases owning more than thirty slaves. ${ }^{10}$ However, the emerging character of this slave regime resulted more from the startlingly high number of slave owners with only one or two slaves.

Large numbers of slaves, perhaps a majority of the city's slave population, were owned by men and women of very modest means. As one visitor put it in 1794, "you should know that there is an increased number of slaves in the city and many families have no property other than their slaves. [ . . T] hese the law obligates to provide their owners with a daily payment". ${ }^{11}$ Many owners, in fact, were completely dependent on the wages of their slaves.

This generalization can be corroborated from a variety of sources. In the manumission documents of the period it was common for slave owners unambiguously to acknowledge their dependence on the earnings of one or more slaves. As a result of this dependence, many slaves gained freedom conditionally, burdened by the requirement to continue making weekly or monthly cash payments during the owner's lifetime. ${ }^{12}$ The city's political institutions also clearly recognized the importance of these transfer payments. In 1789, during a debate over efforts to create a guild of shoemakers, the town council unambiguously asserted the importance of slave wages to families and individuals of limited means. The shoemakers had submitted a guild constitution to the town council that prohibited slaves from attaining the rank of master. The city fathers summarily rejected this constitution, singling out the proposed limitation to the advancement and, therefore, earnings of slaves. This, the councillors noted, "is prejudicial to the Republic, it being apparent that there are many widows and families in this city that sustain themselves with the daily wages of their slaves". ${ }^{13}$

As slave arrivals increased after 1790 slave prices declined slightly thus drawing a larger pool of potential buyers into the market. In 1802, Buenos Aires' first periodical, the Telégrafo Mercantil, offered the following short summary of the city's slave market: "Every day there arrives in our port a frigate with three or four hundred slaves who will be disembarked on our shores. With notice of the arrival, people who wish to begin living a lazy life congregate to seek those who will work

\footnotetext{
10 The concentrated nature of the distribution became very clear when the governing junta sought to conscript slaves during the independence struggle. See Goldberg y Jany, "Algunos problemas referentes a la situación del esclavo en el Rfo de la Plata", IV Congreso Internacional de Historia de América (Buenos Aires, 1966).

"Francisco de Aparicio, "Relación de un viaje entre Mendoza y Buenos Aires en 1794", Anales del Instituto de Etnografia Americana (Mendoza, 1942), vol. III, p. 236.

12 Archivo General de la Nación, Escribanía, Registros 1-7, anos 1776-1810. Approximately 11 per cent of all the manumissions granted during the viceregal period required that the slave continue making a weekly or monthly payment to the owner.

${ }^{13}$ Archivo General de la Nación, Interior, Legajo 26, Expediente 4, 25-25 vta.
} 
in their place. To accomplish this end, each comes with one or two thousand pesos to spend, departing for their home [with a slave or two] very satisfied. Within a few days they obligate their new slaves to walk the streets to find a day's labor that will pay four or five reales:"14 We know that "three or four hundred slaves" did not arrive daily in 1802. Nevertheless, it is clear from surviving accounts that as the volume of imports rose and opportunities for hiring out increased slave ownership did in fact become more common among people of modest means.

It seems unlikely that many recent arrivals from Africa or Brazil were sent into the local labor market with the minimal cultural equipment suggested in the Telégrafo Mercantil article. Unable to speak Spanish and without knowledge of local wage and price custom or knowledge of monetary values, a recent arrival was certain to be a target for abuse and fraud. Of more direct concern to owners was the likelihood that unassimilated and inexperienced slaves would be unable to locate employment at standard rates and would, therefore, fail to provide the adequate return on invested capital. We should presume that only those owners completely overtaken by sloth or completely absorbed in their own affairs would fail to supervise directly the employment contracts of newly-arrived slaves. Indeed, the notarial copybooks seem to suggest that, in longer labor contracts, wages, minus estimated living expenses, were commonly paid directly to slave owners by employers of hired slave labor.

These same records indicate that, rather than sending newly-purchased slaves out on their own, it was more common to place them as apprentices or as helpers with established artisans or lesser-skilled wage workers. At the cost of some lost income, owners delegated direct supervision of their slaves to these employers for a period of two to six years, depending on the trade. As was the case with free apprentices, apprenticed slaves lived in the home of a master who provided room and board and, sometimes after the first year, a small wage. Master artisans were also responsible for instruction in the Catholic faith and discipline. Although less formal arrangements were the norm in the brick kilns, bakeries, stockyards and construction gangs that employed thousands of the city's workers, it was also customary for slaves in these occupations to share meals and sleeping arrangements with free workmates. Nearly every workplace and most workers' housing in late colonial Buenos Aires integrated free and slave workers. ${ }^{\text {is }}$ Since the

14 "Telégrafo Mercantil", Reflexiones cristianas sobre los negros esclavos (Buenos Aires, 1914), vol. II, pp. 191-196. This article is somewhat misleading on the price of recentlyarrived African slaves, bozales. During the last two decades of the colonial era, the price of African males in Buenos Aires fluctuated between 200 and 250 pesos. A slave who became a master artisan could bring as much as 600 pesos.

1s This conclusion is drawn from a close examination of a number of matriculations of artisans from 1780 that show residence arrangements. See the census of Albañiles, for example, in Archivo General de la Nación, Tribunales, Legajo 66, Expediente 15. 
youngest, least-skilled slaves had only limited earning potential, slave owners sought to reduce the cost of skill acquisition and subsistence by transferring these burdens to an employer. As slaves gained experience and acquired skills their income potential grew. Owners generally responded to enhanced earning potential by granting slaves greater freedom to negotiate employment and determine living arrangements. For thousands of slaves in late colonial Buenos Aires, slavery meant weekly or, less commonly, monthly, cash payments paid to their owners. Owners were able to both ratchet up the amounts of these cash payments and increasingly make slaves responsible for their own subsistence as they acquired skills and gained cultural sophistication. In its mature form after 1790, slavery in Buenos Aires was not the paternalistic social system that historians have generally found in other Spanish colonies. Overwhelmingly, the slave owners of Buenos Aires regarded their slaves as investments that they expected to produce regular dividends.

Although the volume of free immigration was consistently inferior to that of the slave trade, free immigrants also entered the Buenos Aires labor market in large numbers after 1776. Unfortunately, colonial officials made no effort to record the arrival of immigrants. Any effort to estimate the scale of immigration, therefore, must rely on population counts compiled for other purposes. These records suggest that the vast majority of free immigrants were young males. According to census counts, the native-born portion of the city's white male population declined from 58 per cent in 1744 to 31 per cent in $1810 .{ }^{16}$ Among manual workers, immigrants were disproportionally found in the skilled artisan trades. Table 2 provides the origins of a cross-section of the city's artisans in 1780. Unfortunately, many artisan occupations and all of the city's lesser-skilled trades (bakers, brick manufacturers, laundresses and others) are excluded from these records. Given what we know of the recruitment practices of the trades excluded from these records, the table probably over-represents the importance of European immigrants in the total workforce. Nevertheless, these matriculations provide the most reliable information available for the origins of the porteño working class. Fortyfive per cent of the city's artisan community were native-born in 1780 and one ninth of these were free blacks. Nearly 41 per cent of all artisans were European immigrants while immigrants from other Spanish colonies in the Americas contributed another 14 per cent.

Among master artisans the importance of immigrants is even clearer. In 1780,59 per cent of all master artisans were immigrants with slightly more than two thirds of all immigrants originating in Portugal or Spain.

\footnotetext{
${ }^{16}$ Portions of the 1810 census have disappeared and, as a result, my estimate of the percentage of native-born based on this census is less reliable than that for 1744. The best analysis of the 1810 census is found in César García Belsunce et al., Buenos Aires: su gente, 1810-1830 (Buenos Aires, 1976).
} 
Table 2. Origins of artisans of Buenos Aires, $1780(\mathrm{~N}=1,045)$

\begin{tabular}{ll} 
Born in Spain or other European nations & $41 \%$ \\
Born in other American colonies & $14 \%$ \\
Born in Buenos Aires or hinterland & $45 \%$ \\
\hline
\end{tabular}

Source: Archivo General de la Nación, Tribunales Legajo 13, Expediente 15; Tribunales, Legajo 66, Expediente 37; Interior, Legajo 9, Expediente 5; Justicia, Legajo 9, Expediente 177; Interior, Legajo 9, Expediente 5; and Tribunales, Legajo 13, Expediente 15.

No comparable records exist for the last decade of the colonial period, but since free immigration clearly increased after 1780 , it is probably safe to conclude that the proportion of immigrants at the upper end of the skill hierarchy changed little before 1810 . At the bottom of the skill hierarchy among apprentices and laborers, on the other hand, slaves and the free native-born contributed slightly more than 80 per cent of the total in 1780 .

\section{WAGES AND EMPLOYMENT}

An upward-ascending wage curve in the city and its hinterland made possible the deep integration of slave and free labor regimes after 1778. ${ }^{17}$ Anticipating that local demand for both skilled and unskilled labor meant that slaves could be quickly placed with employers, men and women of modest means confidently borrowed money to purchase slaves. Wealthier residents also participated in the development of this new labor market. The greater resources available to the elite meant that its members could purchase and hire out larger numbers of slaves. In some cases prosperous merchants combined their ownership of labor resources with investments in small manufacturing enterprises: brickyards, bakeries, hat factories and bronze foundries.

Table 3 provides a wage index for the period 1774-1815. The region's wage history is divided into three periods, each initiated by significant wage increases. The period 1774-1779 began with a decline in wages. The large-scale military activity that accompanied the "creation of the viceroyalty forced down wages, especially for the lesser-skilled. Military wages were low and often in arrears. As a result, off-duty soldiers and sailors entered the local labor market in large numbers, bidding down local wage custom. Once the commercial reform and growth in local public sector spending had taken effect after 1780, wages moved upward, at first hesitantly and then with some strength. A new round of commercial liberalization after 1792 led to a second period of rising wages. Finally, after the British invasions of 1806 and 1807, a rapid expansion

${ }^{17}$ See my "Salarios, precios y costo de vida en el Buenos Aires colonial tardío", Boletin de Historia Argentina y Americana, 3rd series, ler semestre (1990), pp. 133-158, for a preliminary analysis of wages. 
Table 3. Weighted index of wages $(1776=100)$

\begin{tabular}{llll}
\hline 1774 & 105.3 & 1795 & 107.7 \\
1775 & 100.3 & 1796 & 108.4 \\
1776 & 100 & 1797 & 117.1 \\
1777 & 100 & 1798 & 124.6 \\
1778 & 100 & 1799 & 115.9 \\
1779 & 100 & 1800 & 123.4 \\
1780 & 107.5 & 1801 & 123.4 \\
1781 & 101.9 & 1802 & 124.6 \\
1782 & 101.9 & 1803 & 139.6 \\
1783 & 101.9 & 1804 & 139.6 \\
1784 & 107.7 & 1805 & 139.6 \\
1785 & 107.1 & 1806 & 148.1 \\
1786 & 105.2 & 1807 & 151.7 \\
1787 & 105.2 & 1808 & 152.4 \\
1788 & 105.2 & 1809 & 152.3 \\
1789 & 107.7 & 1810 & 177.3 \\
1790 & 105.2 & 1811 & 177.3 \\
1791 & 107.7 & 1812 & 177.3 \\
1792 & 107.7 & 1813 & 177.3 \\
1793 & 105.2 & 1814 & 172.3 \\
1794 & 107.7 & 1815 & 172.3 \\
\hline
\end{tabular}

Note: Weights were assigned to the wage histories of individual occupations based on their proportional importance in contemporary census records. This index includes the wages of carpenters, bricklayers, ironworkers, caulkers, ship carpenters, armsmakers, sailors, urban peones and rural peones.

in regional military manpower requirements exacerbated chronic labor supply problems and inaugurated further increases in the cost of labor.

It is important to note that most of the increase registered by the wage index coincided with periods of greatest slave imports. This suggests that the scale of regional economic expansion and the effects of military manpower requirements allowed Buenos Aires to absorb coerced laborers in large numbers without forcing down the wages of free laborers. In fact, notarial records for the period suggest that there was no measurable wage discrimination experienced by slave workers (or, put more accurately, by the owners of these slave workers). Moreover, because slaves in Buenos Aires commonly had significant discretion in contracting for employment and retained portions of their income, the urban labor force remained flexible and productive even as the numbers of slaves increased.

By 1800 nearly every manual occupation, every skill level, and nearly every job site in the city hosted an integrated workforce of slave and free laborers. However, the documents suggest that racial affinity and racial discrimination played an important role in distributing workers among employers. Legal status seems to have acted in a less intrusive and predictable manner. A close examination of workforce recruitment among the city's artisan shops suggests a deep interpenetration of slave 
and free labor. There is only one surviving craft census that allows us confidently to assign racial identity, a visita conducted on a shop-to-shop basis by a group of master shoemakers and a representative of the cabildo (town council). This visita demonstrates that a clear majority of free nonwhite apprentices and journeymen worked under the supervision of black master artisans. ${ }^{18}$ Among slave apprentices and journeymen who negotiated their own employment, a majority were found in the shops of white master artisans. This suggests to me that free black and mulatto artisans sought to limit discriminatory obstacles to skill acquisition and advancement within their trades by avoiding white employers. Slave artisans, on the other hand, were found in greater numbers in the shops of the more prosperous white masters because of the likelihood that these shops would offer more secure employment and pay higher wages which was the key to eventual manumission.

In the brickyards and bakeries that employed large numbers of workers, every employer mixed free and slave labor. Among artisans, slave and free craftsmen worked together in all but the smallest shops that employed only one or two apprentices or journeymen. Most commonly, free master artisans supervised the labor of a mixed workforce that included both slave and free helpers. Many of these master craftsmen owned the slave apprentices and journeymen they employed. There were also many examples in late colonial Buenos Aires where slaves who had achieved the rank of journeyman or master directed the labor, and even disciplined, free apprentices, or lesser-skilled laborers.

Given the culture of artisan production, the boundaries between slave and free were obscured when free apprentices worked in shops with slave journeymen or masters. In these cases, the slave's authority derived from mastery of skills tended to override the cultural presumption that the free apprentice held higher social status. This inversion was exaggerated in those shops where enslaved master artisans supervised the labor of free journeymen and apprentices. In cases like these we need to pause before assigning traditional labels of free and unfree to the late colonial workforce of Buenos Aires.

The expanded military requirements provoked by the British invasion of 1806 initially drew down free labor supply only. However, with the beginning of the struggle for independence in 1810, the region's revolutionary governments sought to draw slaves into the military. At first, slave owners were encouraged to enlist their slaves as a patriotic contribution. In 1813 these indirect means were abandoned as the government began the conscription of slaves. Those slaves who survived their terms of military service were promised freedom. At the same time the region's new political leadership took the first hesitant step towards the eventual abolition of slavery, the 1813 Ley de libertad de vientes. This

${ }^{18}$ Archivo General de la Nación, Interior, Legajo 41, Expediente 14, 11-17 vta. 
law declared that all children born to slave mothers after 31 January 1813 would be granted freedom after a mandatory period of supervised apprenticeship. ${ }^{19}$ The combination of slave conscription and a rising tide of abolitionist sentiment undermined the links that had earlier tied the Atlantic slave trade to the skilled trades of Buenos Aires. As a result, the mass of slave purchasers, many dependent on borrowed capital, who had sustained demand for slaves before 1813 exited the market.

As urban demand for slaves declined, rural producers, especially estancieros (large-scale ranchers) became primary players in a slowly collapsing slave market. Slavery gained a new lease of life in the countryside as rural labor demands supplied new momentum to the faltering institution. And, as a result, the institution survived for decades after the first efforts at comprehensive abolition were undertaken in the city. However, the employment of slave labor in the province of Buenos Aires after 1815 diverged in character from the urban slave regime that had developed in the last two decades of the colonial period. Unlike the city where slaves commonly arranged their own employment contracts and lived outside the homes of their masters, slaves in the countryside worked for their masters under much closer supervision. With most of the slaves employed in the countryside of Buenos Aires province distributed among ranches and small farms, there was no likelihood that the oppressive system of social control found in plantation zones would appear. Still, this was a fundamentally new work regime for the region: rural slave owners unlike their urban contemporaries sought labor power, not rent.

\section{RURAL PRODUCTION/POSTSCRIPT}

The region's livestock industry lagged behind competitors across the estuary in what is now Uruguay and in the interior provinces to the west. Throughout most of the colonial period, unbranded cattle and horse herds grazed freely on the province's open range. Grazing lands in the province of Buenos Aires had little monetary value before the 1780s. Hides and other by-products like tallow were produced freely by entrepreneurs who purchased the necessary licenses and then organized groups of rural laborers for intense short-term harvests. That is, the cost of producing the region's exports was largely determined by the cost of labor.

As the value of these products increased following liberalization of trade in 1778, land ownership became more important, land values rose,

${ }^{19}$ These libertos were to gain their freedom upon marriage or upon reaching age 16 for women and age 20 for men. They were all required to serve their masters without salary until age 15. From 15 years old until emancipation 1 peso per month was to be deposited on their behalf with the police. 
and systematic efforts were made by landowners to retain a permanent labor force capable of protecting herds and extracting product. By the 1790 s colonial authorities had required rural workers to carry cards proving employment under pain of conscription or incarceration. These changes in land values and labor practice coincided with significant new investment in rural property. Especially after 1809 when direct trade with Great Britain overwhelmed traditional commercial arrangements with Spain, important local merchant families began to invest in rural properties. Not only did these investments intensify the demand for rural labor, but these politically powerful families were also capable of bending the coercive powers of the state to meet their needs. As foreign demand for the region's products expanded in the 1820s, rural workers were forced to accept even more draconian labor laws. Ranchers and their foremen were granted de facto control of courts, jails, and corporal punishments to discipline and compel the labor of free men and women. ${ }^{20}$ Rural slaves faced a work regime that was even more coercive.

The labor shortages of the city between 1780 and 1810 and the countryside after 1820 both led to increased dependence on slave labor. Yet the slave systems that evolved in the city and countryside were very different. Unlike the labor market of the late colonial city, both slave and free workers in the early national countryside were prevented from negotiating improved employment conditions or higher wages by contract and license laws imposed by the state. Rural slaves were also generally denied the opportunities for manumission that had been associated in the city with the acquisition of skills and improved income that came from employment in artisan and other skilled trades. In addition, rural slave owners would also prove to be more effective in slowing the progress of abolition than urban masters.

Without significant new slave importations, slave labor declined in relative importance after 1830 as free immigration expanded. Nevertheless, the residual slave population continued in the relentless grip of the estanciero class. Slave owners used various schemes to keep their slaves, despite government emancipation laws. Few of the libertos "freed" by the 1813 law, for example, actually experienced freedom before middle age. Many were held in bondage illegally when the police records that contained their birth dates, and therefore the date of their emancipation, conveniently disappeared in 1831 .

As the political power of the rural elite increased after 1820 , the estanciero class initiated efforts to import new slaves. Thousands of slaves seized from Brazilian shipping by local privateers during wartime were admitted to the province in clear violation of an 1825 treaty with

${ }^{20}$ Many authors have written on this topic. See Slatta, Gauchos, especially ch. 7; and John Lynch, Argentine Dictator. Juan Manuel de Rosas, 1829-1852 (London, 1981), especially ch. 3: "Patrón and Peon". 
Great Britain that had abolished the slave trade. Then, despite British protests, the powerful governor of the province, Juan Manuel de Rosas, briefly legalized the slave trade in 1831 . But these schemes added only a few thousand new slaves, commonly identified by the euphemism libertos, to the provincial workforce. Following Rosas' overthrow in 1852 , the new national constitution of 1853 abolished slavery unambiguously. But, again, liberation was denied to the province's small remaining slave population when the local political elite revolted against the national government. As a result, slavery was not finally abolished in Buenos Aires until 1861 when the province finally rejoined the national union.

The labor history of the province of Buenos Aires, 1776-1850, suggests that slave and free workers could be compatibly integrated in both urban manufacturing and service sectors and in rural livestock and small farming production. Moreover, the Buenos Aires case indicates the blurred boundaries that separated free and slave workers, especially in urban occupations. In an artisan culture where slave journeymen arranged their own labor contracts and free apprentices were sometimes supervised by slaves who were master artisans, the distinctions between free and coerced labor are stipulated only with great difficulty. What is needed, especially in the regions outside the plantation economies of the Americas, is additional research that places the experiences of slaves in a context broadened to include wage workers as well. 